Original Research Paper

\title{
The Effect of Red Paprika Juice (Capsium annum) Addition into the Feed to Brightness of The Red Comet Fish Colour (Carassium auratus)
}

\author{
Anisa Larasati Humairo ${ }^{1 *}$, Muhammad Junaidi ${ }^{1}$, Muhammad Marzuki ${ }^{1}$ \\ ${ }^{1}$ Department of Fisheries and Marine Science, Mataram University, Mataram, Indonesia
}

\section{Article History}

Received : August $25^{\text {th }}, 2021$

Revised : September $15^{\text {th }}, 2021$

Accepted : September $28^{\text {th }}, 2021$

Published : October $02^{\text {th }}, 2021$

*Corresponding Author: Anisa Larasati Humairo, Department of Fisheries and Marine Science, Mataram University, Mataram, Indonesia Email:

Anisalarasatihumairo@gmail.com

\begin{abstract}
This study aims to determine the color change of comet fish (Carasium auratus) after being given additional feed in the form of red paprika juice. Measurement of the fish color was carried out every 10 days for 1 month and visual observations were made with digital photos and analyzed the colors using Adobe Photoshop CS4 software. In this study, different concentrations of paprika juice were used. This study used a completely randomized design (CRD). There were 5 treatments, namely P0 without the addition of red paprika juice (control), P1 with the addition of $2 \%$ paprika juice, $\mathrm{P} 2$ with the addition of $4 \%$ paprika juice, P3 with the addition of $6 \%$ paprika juice, and $\mathrm{P} 4$ with the addition of $8 \%$ paprika juice, which was performed on 3 times for each. The research data were analyzed using statistical analysis Unvariate One Way Analysis of Variance at 5\% level with a $95 \%$ confidence interval. The results showed that the highest increase in color quality was obtained in the P3 treatment with an average value of $63.85 \pm 2.12$, the highest specific weight growth rate was obtained in P3 treatment with an average value of $60.825 \pm 0.59$ days, the highest specific length growth rate was obtained atP3 treatment with an average value of $1.37 \pm 0.28$ grams, while at the survival rate there is a significant value or not significantly different. The conclusion of this study is the effect of adding red paprika juice in the feed affects the color quality and specific growth rate, while the survival rate is not affected. Furthermore, the dose of red paprika juice added to the feed can improve the color quality of comet fish with the highest value found in $\mathrm{P} 3$ (with the addition of $6 \%$ paprika juice), namely 63.85 .
\end{abstract}

Keywords: Comet fish, red paprika, color quality.

\section{Introduction}

One of the biodiversity that Indonesia has and should be proud of is the diversity of freshwater ornamental fish species. The potential of Indonesian waters has a unique and abundant diversity of ornamental fish therefore it is called as a home for hundred of exotic ornamental fish species. There are 240 types of marine ornamental fish and 226 types of fresh water ornamental fish (Khoironi, 2017). This makes the cultivation of freshwater ornamental fish being a good prospect.

The export value of ornamental fish experienced fluctuations from year to year. It was US \$ 8.3 million in 2008 and US \$ 10.0 million in 2009 (Riantono, 2016). Indonesia is the 5th exporter of ornamental fish in the world which is able to take the market up to $7.13 \%$. This number is still less than Singapore, the world's main exporter, which reaches $12.44 \%$ (KKP, 2017). From 2015 to 2018 the number of Indonesian ornamental fish exports has reached 257,862,207, where the destination countries are dominated by Japan, Singapore, United States, China, United Kingdom, Korea and Malaysia (KKP, 2019).

One type of freshwater ornamental fish which is owned by Indonesia, namely the comet fish. This fish is in demand, especially from its color variations such as plain white, red, orange, black, yellow, red and white, red-yellow, blackwhite, black-brown, black-red and white yellow. 
Local comet fish usually have a cheaper price than imported comet fish because of their faded color performance.

The color of ornamental fish is one of the most influencing factors on the selling price of the fish. The comet fish (Carassius auratus) is an ornamental fish that has a faded yellow to red color. This fish is very popular and has a high selling value in the ornamental fish trade forum. The selling price of comet fish will be optimal if the color looks yellow and reddish orange. However, the color of ornamental fish generally fades when kept in an aquarium. One of the causes is environmental stress, including the different environment between the aquarium and the original habitat, sunlight, water quality, and pigment content in the feed.

Fish need to be given feed that can support the brightness of their color because feed factors have an influence on the formation of ornamental fish color (Nazhira, 2017). Chromatophores are pigment cells that cause color formation in fish. Chromatophores are found in the dermis on the scales, outside or under the scales. Red or yellow is the color that dominates many ornamental fish. Carotenoid pigments are the main components of red and yellow pigments (Subamia, 2010).

$\beta$-carotene is one of about 500 carotenoids in nature and has the highest Vitamin A activity. Several sources of high $\beta$-carotene, one of which is found in red peppers. In addition, $\beta$-carotene is also found in spirulinaflour, carrots and pumpkin. However, consuming too much $\beta$ carotene can be dangerous because it contains nitrosamides, nitrites, and falcarinol (Taqiyuddin, 2015).

The number of studies using natural dyes from carrot flour to enhance the color of goldfish (Karo karo, 2015), spirulina flour for color enhancement of koi fish (Andriani, 2018), shrimp head flour to increase color brightness of koi fish (Subamia , 2013) and pumpkin flour which is used to increase the color of the goldfish (Solihah, 2015), while those who use red pepper juice are still very few because they have a high risk of death in the biota that will be maintained because of their slightly spicy taste (Tjahjaningsih, 2015).

Based on the background, therefore it is necessary to conduct research on "The effect of adding red pepper juice (Capsium annum) in the feed on the brightness of the comet fish (Carassius auratus) color.

\section{Material and Methods}

This research was conducted from October to November 2020 in a private installation in Lendang Nangka village, Masbagik District, East Lombok Regency, West Nusa Tenggara.

The research method used was an experimental method using a Completely Randomized Design (CRD) consisting of 5 treatments with different stocking densities of vaname shrimp. Each treatment was repeated 3 times in order to obtain a 15-unit experiment. This research was conducted on 30 days. The research design can be seen in Table 1

\section{Research Parameters}

The parameters analyzed statistically were the increase in color quality, the specific weight growth rate (SGR), the specific length growth rate, and the survival rate (SR).

Calculation of the daily specific growth rate (weight) was carried out to determine the average growth of comet fish from the beginning of the study to the end of the study (Utami, 2018).

$\mathrm{SGR}=\stackrel{\ln \mathrm{Wt}-\ln \mathrm{Wo}_{0}}{\mathrm{x}} 100 \%^{\mathrm{t}}$

Information:

SGR : Daily specific growth (\% / day)

Wo : Average fish weight at the beginning of rearing $(\mathrm{g})$

Wt: Average fish weight at the end of rearing $(\mathrm{g})$ $\mathrm{t}$ : Maintenance time (days)

Calculation of the daily specific growth rate (length) was carried out to determine the total growth of comet fish from the beginning of rearing to the end of rearing (Agustin, 2014).

$\underline{\operatorname{lnLt}-\operatorname{lnLo}} \times 100 \%{ }^{\mathrm{t}}$

Information:

Lt: Average length of fish at study entry Lo: Average length of fish at the end of the study Q: maintenance time

The percentage of comet fish survival is done by looking at the number of fish at the beginning of maintenance and at the end of maintenance which can be calculated by the formula from (Agustin, 2014). 
as follows: $\mathrm{SR}=\stackrel{\mathrm{Nt}}{\mathrm{x}} 100 \%$

$$
\text { No }
$$

Information :

SR: Survival (\%)

$\mathrm{Nt}$ : Number of fish that live at the end of rearing (tail) No: Number of fish at the beginning of maintenance

\section{Data Analysis}

Data from the research results were analyzed by using Analysis of Variation (ANOVA) with Statistical Product and Service Solutions (SPSS) at a significant level of 0.05 or with $95 \%$ accuracy to determine the effect of the treatment in the study. If the data shows a real effect, then further analysis is carried out with Duncan (Kurniawan, 2015).

\section{Color Quality}

Based on the results of analysis of variance (ANOVA) at the 95\% confidence level, it showed that the increase in color quality in the combination treatment of Red Paprika Juice showed significantly different results between treatments. The results of data analysis in graphical form can be seen in Figure 1.

Figure 1. The Value of Increased Brightness of Comet Fish Color

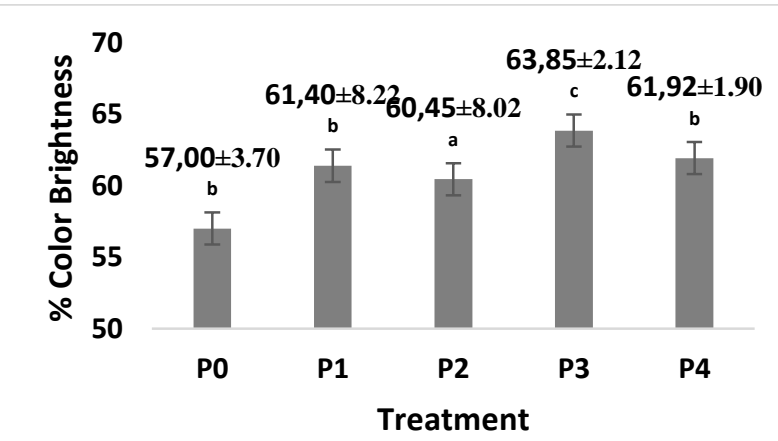

The effect of adding red pepper juice in the feed has a significant effect on the improvement of color quality. The control treatment (without paprika juice) was not significantly different with $2 \%$ addition (P1) and $8 \%$ (P4) addition of paprika, while the addition of $4 \%(\mathrm{P} 2)$ and the addition of $6 \%(\mathrm{P} 3)$ paprika juice was different real. The increase in color quality with the addition of $2 \%$ paprika (P1) was significantly different from $4 \%=$ addition $(\mathrm{P} 2)$ and 6\% (P3) of paprika juice. The increase in color quality with the addition of paprika juice $4 \%$ (P2) was significantly different from $6 \%$ addition (P3) and 8\% (P4) of paprika juice. The increase in color quality with 6\%0addition of paprika juice (P3) was significantly different from the addition of $8 \%$ paprika juice (P4) (Figure 1).

\section{Specific Weight Growth Rate}

Based on the results of analysis of variance (ANOVA) at the 95\% confidence level, it shows that the absolute weight in the combination treatment of Red Paprika Juice shows the results are significantly different between treatments, this is because the value $(p>0.05)$ The results of data analysis in graphical form can be seen in Figure 2.

Figure 2. Comet Fish Absolute Weight Growth

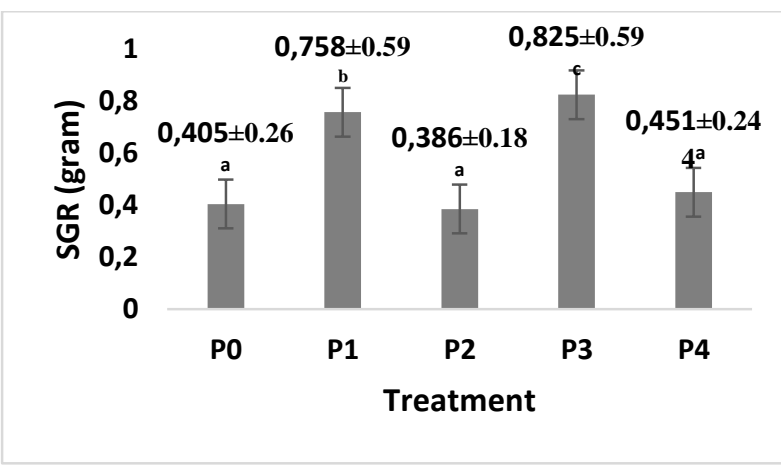

The effect of adding red pepper juice in the feed had a significant effect on the growth rate of specific weight. The control treatment (without paprika juice) was significantly different from the addition of $2 \%$ paprika (P1) and the addition of $6 \%(\mathrm{P} 3)$ peppers, while the addition of $4 \%$ paprika juice (P2) and the addition of $8 \%$ paprika juice (P4) were not significantly different. The specific growth rate of weight with the addition of $2 \%(\mathrm{P} 2)$ peppers was significantly different from the addition of $4 \%(\mathrm{P} 2), 6 \%(\mathrm{P} 3)$ and $8 \%$ (P4) juice. The specific weight growth rate with the addition of $4 \%(\mathrm{P} 2)$ paprika juice was significantly different from the addition of $6 \%$ (P3) paprika juice, while the addition of $8 \%$ paprika juice (P4) was not significantly different. 


\section{Specific Length Growth Rate}

Based on the results of analysis of variance (ANOVA) at the 95\% confidence level, it showed that the absolute length of the combination treatment Red Paprika Juice showed significantly difference between treatments, this was because of the value ( $p>0.05$ ). The results of data analysis in graphical form can be seen in Figure 3.

Figure 3. Value of Absolute Length Growth

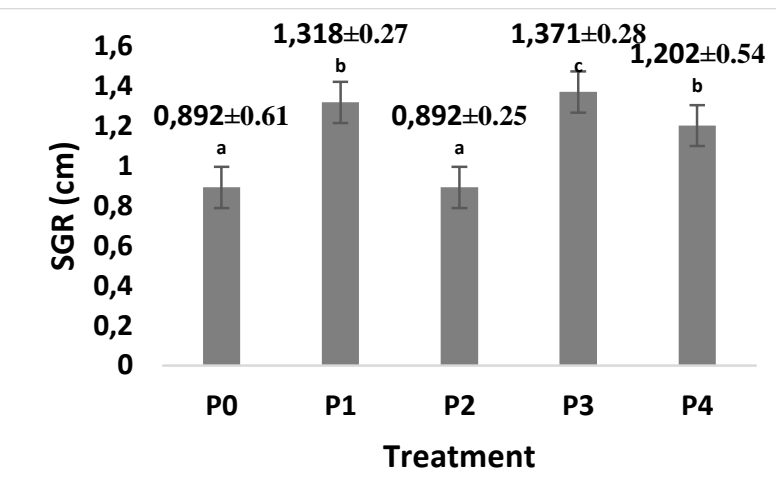

The effect of adding red pepper juice in the feed had a significant effect on the specific length growth rate. The control treatment (without paprika juice) was significantly different from the addition of $2 \%$ paprika (P1) and the addition of $6 \%$ (P3) peppers, while the addition of $4 \%$ paprika juice (P2) and the addition of $8 \%$ paprika juice $(\mathrm{P} 4)$ were not real different. The specific growth rate of length with the addition of $2 \%$ (P2) peppers was significantly different from the addition of $4 \%(\mathrm{P} 2), 6 \%(\mathrm{P} 3)$ and $8 \%(\mathrm{P} 4)$ juice. The specific weight growth rate with the addition of $4 \%$ (P2) paprika juice was significantly different from the addition of $6 \%$ (P3) paprika juice, while the addition of $8 \%$ paprika juice (P4) was not significantly different.

\section{Survival Rate (SR)}

Based on the results of analysis of variance (ANOVA) at the 95\% confidence level, it shows that the survival rate in the combination treatment of Red Paprika Juice showed no significant different between treatments. The results of data analysis in graphical form can be seen in Figure 4.
Figure 4. Values of Survival

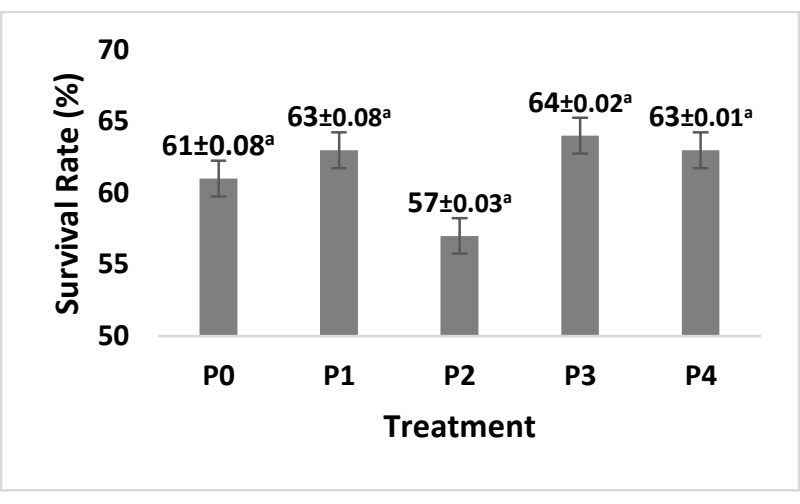

Based on Figure 4 on the survival rate (SR) of comet fish with the addition of red pepper juice with different concentrations, the results were obtained, showed that all treatments had no significant difference (Figure 4).

Table 1. Water Quality

\begin{tabular}{lrrrrrl}
\hline Parameters & \multicolumn{4}{c}{ Treatment } & \multicolumn{3}{c}{ Refrence } \\
& \multicolumn{1}{c}{ P } & P1 & P2 & P & P4 & \\
& 0 & & & 3 & & \\
\hline Temp $\left({ }^{\circ} \mathrm{C}\right)$ & 2 & 21 & $21-24$ & 2 & 21 & $22-37$ \\
& 3 & - & & 1 & - & Lesmana \\
& - & 24 & & - & 24 & $(2007)$ \\
& 2 & & & 2 & & \\
$\mathrm{pH}$ & 4 & & & 4 & & \\
& 6 & $6-$ & $6-7$ & 6 & $6-$ & $6,5-8,0$ \\
& - & 7 & & - & 7 & Lesmana \\
& 7 & & & 7 & & $(2002)$ \\
\hline
\end{tabular}

Water quality measured during the study can be seen in Table 1. Temperature was measured every morning before feeding every 10 days, $\mathrm{pH}$ and temperature were measured at the beginning of maintenance, day 10, day 20 and day 30 of maintenance.

\section{Improved Color Quality}

The result observations that have been carried out show that comet fish that are given additional red pepper juice in the feed which has the highest value or the best results are found in the addition of $6 \%$ paprika juice treatment in accordance with Putriana's statement (2015) which stated that red pepper juice can increase brightness. In the color of the fish, it is better if the addition of paprika juice is not more than $7 \%$, because in previous studies the addition of $7 \%$ to 
$10 \%$ paprika juice resulted in the fish being dead. The decrease in color quality is thought to be due to stress when taking samples for color observation. According to Antono (2010) in Karo-karo (2014) that stress on comet fish or other ornamental fish will generally have a negative impact on the color of the fish. With this statement it is assumed that the decrease in color quality is not due to the addition of paprika juice to the feed. To reduce the chances of stress occurring in fish, it is better to provide a duration when making observations so that the fish will not run out of oxygen and stress.

\section{Specific Weight Growth Rate}

The results of the observation of the specific growth rate were the supporting parameters that were observed to determine the effect of adding red pepper juice to the feed. The results showed that there was a difference in growth in each treatment (Figure 5). Based on the One-Way Anova statistical analysis (Appendix 2 shows the effect of the feeling of red peppers on the specific growth rate of comet fish. To determine the degree of difference between treatments, a further test was carried out using Duncan's (Appendix 2). Duncan's test results gave significantly different values in all treatments.

The highest specific growth rate of comet fish was in treatment P3 while the lowest specific growth rate was in treatment $\mathrm{P} 2$. The highest length growth value was 1.371 and the lowest length growth value was 0.892 . Furthermore, the highest weight growth value is 0.825 and the lowest weight value is 0.386. According to Rakhfid (2017), growth is influenced by many factors, one of which is the cleanliness and effectiveness of maintenance time in cultivation, which is obtained by looking at the growth rate of these fish. One of the factors that causes the high growth rate is the handling and maintenance of fish such as the effectiveness of maintenance time, control and the cultivation environment (Nababan, 2017). (Figure 2).

\section{Survival Rate}

The results of the observation of the OneWay Anova test statistical analysis showed that the highest survival was shown by P3 (addition of $6 \%$ paprika juice) which was $64 \%$ and the lowest survival was in P2 (addition of $4 \%$ paprika juice) which was $57 \%$. Survival is affected by water and feed quality. The factors that most influence the survival rate of fish are water quality in the maintenance medium and feed quality (Lestari, 2018). Based on observations, it is known that the survival rate of all treatments shows a high enough value, this is presumably because the water quality during maintenance is in optimal conditions and can be tolerated by comet fish.

Water quality parameters used in this study were temperature and $\mathrm{pH}$ (graph 4). During the study, the temperature ranged from $23-26^{\circ} \mathrm{C}$. According to Lesmana (2002) in Fitriana (2013) this temperature is still within the optimal limit for fish maintenance, which is between $22-27^{\circ} \mathrm{C}$. The $\mathrm{pH}$ of the water during the study ranged from 7-8. According to Lesmana (2007) in Karo-Karo (2014) that the optimal $\mathrm{pH}$ for comet fish rearing is between 6.5-8.0 so that it will not affect the growth and survival of the fish.

\section{Conclusion}

Based on the results of the study, the effect of adding red pepper juice in the feed affected the color quality and specific growth rate, the survival rate was not affected. Furthermore, the dose of red paprika juice added to the feed can improve the color quality of comet fish with the highest value found in P3 (with the addition of $6 \%$ paprika juice), namely 63.85 .

/ L. Meanwhile, the $\mathrm{pH}$ value ranges from 7.6 8.3. This $\mathrm{pH}$ range is very good for the survival of koi fish, according to Effendi (2003), which states that water that is good for fish farming is a neutral range with a $\mathrm{pH}$ of 7.0-8.0. Meanwhile, Agus et al. (2002) in Putriana (2015) who swim in waters that are optimal for koi fish growth ranges from $6.5-8.5$.

\section{References}

Agustin, R., Sasanti, A.D., \& Yulisman (2014). Konversi Pakan, Laju Pertumbuhan, Kelangsungan Hidup Dan populasi Bakteri Benih Ikan Gabus (Channa striata) Yang Diberi Pakan Dengan Penambahan Probiotik. Jurnal Akuakultur Rawa Indonesia. 2(1): 55-66.

Andriani, Y., Alan, A., Rosidah \& Walim, L. (2018). Pengaruh Penambahan Tepung Spirulina platensis dan Tepung Wortel 
Terhadap Kecerahan Warna pada Ikan Koki (Carassius auratus) Oranda. Jurnal Perikanan dan Kelautan. 8(1): 1-9.

Andriani, Y., Tia, R.S.M., Ayi, Y., Iskandar \& Irfan, Z. (2018). Kualitas Warna Benih Ikan Mas Koki (Carassius auratus) Oranda Pada Berbagai Tingkat Pemberian Tepung Spirulina platensis. Chimica et Natura Acta. 6(2): 49-55.

Fitriana, N., I Wayan, S., \& Seno, W. (2013). Pertumbuhan dan Performansi Warna Ikan Mas Koki (Capsium sp.) Melalui Pengayaan Pakan Dengan Kepala Udang. Jurnal Biologi. 6(2).

Hapsari, Amalia (2014). "Isolasi dan Identifikasi Fungi Pada Ikan Maskoki (Carassius auratus) di Bursa Ikan Hias Gunung Sari Surabaya, Jawa Timur". Skripsi. Fakultas Perikanan dan Kelautan, Universitas Airlangga Surabaya.

Indarti, S., Muhaemin, M. \& Hudaidah, S. (2012). Modified Toca Colour Finder (Mtcf) Dan Kromatofor Sebagai Penduga Tingkat Kecerahan Warna Ikan Komet (Carasius Auratus Auratus) Yang Diberi Pakan Dengan Proporsi Tepung Kepala Udang (Tku) Yang Berbeda. e-Jurnal Rekayasa dan Teknologi Budidaya Perairan. 1(1):9-16.

Iswardi yantok (2014). Prevalensi Dan Intensitas Ikan Maskoki (Carassius auratus) Yang Terserang Lernaea cyprinacea Di Sentra Budidaya Ikan Maskoki Kabupaten Tulungagung, Jawa Timur. Skripsi. Fakultas Perikanan Dan Kelautan Universitas Airlangga Surabaya.

Karo-Karo R. M. S., Syammaun U., \& Irwanmay (2015). Pengaruh Konsentrasi Tepung Wortel (Daucus carota) pada Pakan terhadap Peningkatan Warna Ikan Mas Koki (Carassius auratus). J. Aquacoastmarine. 10(5):1-10.

Khoironi F. E. \& Ida Ayu N. S. (2017). Analisis Pengaruh Kurs Dollar, Inflasi, Dan Produksi Terhadap Ekspor Ikan Hias Di
Provinsi Bali. E-Jurnal Ekonomi Pembangunan Universitas Udayana. 6(3).

KKP (Kementrian Kelautan dan Perikanan) (2017). KKP Dorong Indonesia Rajai Pasar Ikan Hias Dunia. https://kkp.go.id/artikel/1100-kkpdorong-indonesia-rajai-pasar-ikan-hiasdunia [diakses pada tanggal 27 Agustus 2019]

(2019). KKP Serius Garap Potensi Budidaya Ikan Hias Nasional.

https://kkp.go.id/djpb/artikel/12566-kkpserius-garap-potensi-budidaya-ikan-hiasnasional [diakses pada tanggal 27 Agustus 2019]

Kordi, M. G. (2010). Panduan Lengkap Memelihara Ikan Air Tawar Dikolam Terpal. ANDI. Yogyakarta.

Kurniawan, S.A., Pramonowibowo., S. \& Boesono, H. (2015). Analisis Perbedaan Umpan Dan Kedalaman Pada Pnacing Kalar Terhadap Hasil Tangkap Ikan Gabus (Ophiocepalus striatus) di Perairan Rawa Pening, Kabupaten Semarang. Journal of Fisheries Resources Utillization Management And Tecnology. 4(2).

Lestari, I., Suminto \& Tristiana, Y. (2018). Penggunaan Copepoda, Oithona sp. sebagai Substitusi Artemia sp. Terhadap Pertumbuhan dan Kelulushidupan Larva Udang Vaname (Litopenaeus vannamei). Journal of Aquaculture Management and Technology. 7 (1).

Merlin, N.P.U., Samidjan, I., \& Pinandoyo (2017). Penambahan Tepung Bunga Marigold (Tagetes Erecta) Pada Pakan Buatan Untuk Meningkatkan Kecerahan Warna Ikan Rainbow. Journal of Aquaculture Management Anf Tecnology. $6(3)$.

Nababan, E., Iskandar, P., \& Rusliadi (2015). Pemeliharaan Udang Vaname (Litopenaeus vannamei) dengan Persentase Pemberian Pakan yang 
Berbeda. Jurnal Perikanan dan Ilmu Kelautan. 1(1).

Rakhfid, A., Nur, B., Muh, B., \& Fendi, F. (2017). Pertumbuhan dan Kelangsungan Hidup Udang Vaname (Litopenaeus vannamei) pada Padat Tebar Berbeda. Jurnal Akuakultur, Pesisir Dan PulauPulau Kecil. 1 (2).

Riantono F., Kismiyati \& Laksmi S. (2016). Perubahan Hematologi Ikan Mas Komet (Carassius auratus auratus) Akibat Infestasi Argulus Japonicus Jantan dan Argulus Japonicus Betina. Journal of Aquaculture and Fish Health. 5(2).

Said D. S., W.D. Supyawati \& Noortiningsih (2005). Pengaruh Jenis Pakan dan Kondisi Cahaya Terhadap Penampilan Warna Ikan Pelangi Merah (Glossolepis incises) Jantan. Jurnal Iktiologi Indonesia. 5(2).

Solihah, R., Buwono, I.D., \& Herawati, T. (2015). Pengaruh Penambahan Tepung Labu Kuning dan Tepung Kepala Udang Terhadap Peningkatan Kualitas Warna Ikan Mas Koki (Carrasium auratus). Jurnal Perikanan Kelautan. 2 (1).

Subamia W., Nina M., \& Karunia L. M. (2010). Peningkatan Kualitas Warna Ikan Rainbow Merah (Glossolepis 944 ncises, weber 1907) Melalui Pengkayaan Sumber Karotenoid Tepung Kepala Udang Dalam Pakan. Jurnal Iktiologi Indonesia. 10(1): 1-9.

Subamia W., Nina M., \& Asep P. (2013). Peningkatan Kualitas Warna Kuning Dan Merah Serta Pertumbuhan Benih Ikan Koi Melalui Pengayaan Tepung Kepala Udang Dalam Pakan. J. Ris. Akuakultur. 8 (3): 429-438

Sukarman \& Rina Hirnawati (2014). Alternatif Karotenoid Sintetis (Astaxantin) Untuk Meningkatkan Kualitas Warna Ikan Koki (Carassius auratus). Widyariset. 17(3): $333-342$.
Taqiyuddin M. Z. (2015). Analisa $\beta$-Karoten pada wortel (Daucus carota) dengan menggunakan spektrofotometer Tampak. Skripsi. Fakultas Teknik Universitas Diponegoro Semarang.

Utami, K.P., Hastuti, S., \& Nugroho, R.A. (2018). Pengaruh Kepadatan Yang Berbeda Terhadap Efisiensi Pemanfaatan Pakan, Pertumbuhan Dan Kelangsungan Hidup Ikan Tawes (Puntius javanicus). Jurnal Sains Akuakultur Tropis. 2(2).

Putriana, N., Tjahjaningsih, W., \& Alamsjah, M.A. (2015). Pengaruh Penambahan Perasan Paprika Merah (Capsium annum) dalam Pakan Terhadap Kecerahan Warna Ikan Koi (Cyprinus carpio L.) Jurnal Ilmiah Perikanan dan Kelautan. (7)2. 